\title{
DNA Extraction from Several Cacti
}

\author{
Candelario Mondragon-Jacobo ${ }^{1}$, Natalia Doudareva, ${ }^{2}$ and \\ Bruce P. Bordelon ${ }^{3}$ \\ Horticulture and Landscape Architecture Department, Purdue University, \\ West Lafayette, IN 47906-1165
}

\begin{abstract}
Additional index words. Opuntia ficus-indica, O. humifusa, O. albicarpa, Stenocereus sp., Echinocereus roetteri, Nopalea cochellinifera, Cleistocactus sp., randomly amplified polymorphic DNA, RAPD, mucilage
\end{abstract}

\begin{abstract}
A method for extraction of high quality DNA from four Opuntia sp. and other cacti using a hexadecyltrimethylammonium bromide (CTAB) method is described. These plants typically contain high levels of mucilages, complex polysaccharide compounds that bind water, thus preventing DNA extraction by common miniprep methods. The method involves adjusting the amount of tissue used according to species and age, followed by processing in an extraction buffer to separate coarse material. Extended centrifugation and digestion time in a separation buffer with CTAB (2\%) was used. Exposing tissue to both buffers maintained polysaccharides in solution and allowed easier recovery of the aqueous phase that contains the DNA. We found that 5-8 g were needed to obtain up to 153 $\mu \mathrm{g} \cdot \mathrm{g}^{-1}$ of DNA from tender tissue. Old tissue yielded $26 \%$ less. Extraction of DNA from 5-g samples of tender tissue of the ornamental cacti Stenocereus sp., Cleistocactus sp., and Echinocereus sp. was successful. For these species, average yields ranged from 25 to $53 \mu \mathrm{g}$ per sample. The DNA obtained was suitable for polymerase chain reaction (PCR) amplification, producing clear, distinctive, and reproducible banding patterns useful for a variety of applications.
\end{abstract}

Cactus pear [Opuntia ficus-indica (L.) Mill.] is gaining popularity as an alternative crop for semiarid lands (Nobel, 1994; Mizrahi et al., 1997). The need for improved varieties is of primary importance. Traditional breeding may be facilitated by analyzing the genetic variation in existing cultivars and wild populations using molecular marker technology.

The first step for the application of a molecular approach to any species is to develop techniques to extract high quality DNA. To our knowledge, no previous reports of DNA extraction from cacti are available. We attempted to extract DNA with several miniprep methods that were reported to be fast and reliable with other plants possessing polysaccharides (Dellaporta et al., 1983; Doyle and Doyle, 1990; Haymes, 1996; Rowland and Nguyen, 1993); however, they failed to work with cacti. Two other methods for isolating DNA that could be amplified were partially successful: a modification of the Dellaporta

Received for publication 10 June 1999. Accepted for publication 23 Dec. 1999. Journal paper no. 16013 of the Purdue Univ. Agricultural Experiment Station. We thank D.L. Gottlieb from the Laboratory of Evolution and Ecology, Dept. of Biological Sciences, Univ. of California, Los Angeles, for providing us with the original version of the protocol used for Clarkia species. The cost of publishing this paper was defrayed in part by the payment of page charges. Under postal regulations, this paper therefore must hereby marked advertisement solely to indicate this fact.

${ }^{1}$ To whom request reprints should be addressed. Current address: Nogal 259 Fracc. Arboledas. Queretaro, QRO. 76140, Mexico. E-mail address: jacobo77@ @otmail.com.

${ }^{2}$ Assistant Professor.

${ }^{3}$ Associate Professor. method (Dellaporta et al., 1983) developed by Mackenzie (personal communication) and the method of Varadarajan and Prakash (1991), which provided low yields $\left(<500 \mathrm{ng} \cdot \mathrm{g}^{-1}\right.$ of tissue), therefore limiting the number of applications

In our trials, the main problem was binding of water in the extraction buffer by mucilages present in the tissue, producing a gel-like mixture that prevented all further processing. The mucilage present in cactus is commonly described as a water-soluble, pectin-like polysaccharide (Cardenas et al., 1997). Loik and Nobel (1991) and Nobel et al. (1992) reported that cactus mucilage has a substantial water-binding capacity. The ability of the Cactaceae to retain water under unfavorable climatic conditions is due in part to this property (Nobel, 1988). These compounds have been associated with tolerance to low temperatures in Opuntia humifusa RafinesqueSchmaltz (Loik and Nobel, 1991), and to drought in $O$. ficus-indica L. (Goldstein and Nobel, 1991). Mucilage is present in the chlorenchyma and the adjacent portions of the water-storing parenchyma cells (Nobel et al., 1992). We observed that cultivated Opuntia sp. contain mucilage in all organs, including the floral structures. Many cacti secrete mucilage in response to wounding, and, in the process of DNA extraction, mucilage is evident as soon as the tissue is thawed after grinding.

Mucilage content varies among species. Nobel et al. (1992) reported an average of $34 \%$ on a dry weight basis in stems of three cacti: Echinocereus roetteri Engelman, Opuntia acanthocarpa Engelman and Bigelow, and $O$. basilaris Engelman and Bigelow. However, they found no mucilage in stems of Ferocactus acanthodes (Lemaire) Britton and Rose.
We present a hexadecyltrimethylammonium bromide (CTAB) method that has been adapted for extraction of DNA from several cacti and can probably be generalized with minor adjustments, such as sample size, to other cacti that contain mucilage. The main differences from other protocols are amount and source of tissue, reduction of carryover mucilage after the chloroform extraction by using a separation buffer that contains $2 \%$ $\mathrm{CTAB}$, and extended times of digestion and centrifugation.

\section{Materials and Methods}

Plant materials. DNA was extracted from cultivated and wild cactus pear (Opuntia sp. and Nopalea cochellinifera Salm-Dyck) and the ornamental cacti Cleistocactus sp., Echinocereus roetteri Engelman, and Stenocereus pruinosus (Otto) Buxbaum grown in a greenhouse. The extraction procedure was modified from the protocol used by Gottlieb et al. (unpublished data) to extract DNA from Clarkia species. Pieces of the uppermost edges of tender cladodes were removed with a clean razor. For Cleistocactus sp. and Stenocereus pruinosus, both columnar cacti, we selected very young branches and excised the 5-cm tip. For Echinocereus sp., a spherical cactus, we used young offshoots. Thorns and glochids were removed, and the tissue was washed thoroughly with cold water and blotted dry. Older tissue was also assayed, but it was more difficult to process because of its higher content of fiber and cuticular wax. For older tissue, we selected the chlorenchyma (external photosynthetic green tissue), avoiding the white, spongy, internal tissue, which has a lower number of cells and therefore lower yields of DNA. Because these plants are succulent, grinding can be difficult and slow. Repeated addition of liquid nitrogen avoided thawing and reduced mucilage secretion, making the samples easier to handle. All tissues were extracted on the same day they were collected.

DNA extraction. The extraction buffer contained: $100 \mathrm{~mm}$ Tris [(hydroxymethyl) aminomethane]-HCl, pH 8.0; $1.4 \mathrm{M} \mathrm{NaCl}$; $20 \mathrm{~mm}$ disodium EDTA; $2 \%(\mathrm{w} / \mathrm{v})$ CTAB. Prior to use, $0.25 \% \beta$-mercaptoethanol (v/v) and $0.25 \%(\mathrm{w} / \mathrm{v})$ insoluble polyvinylpirrolydone (PVP) were added. The separation buffer contained: $100 \mathrm{~mm}$ Tris- $\mathrm{HCl}, \mathrm{pH}$ 8.0;20 mm disodium EDTA; $2 \%$ (w/v) CTAB Prior to use, $0.25 \% \beta$-mercaptoethanol (v/v) was added. Other solutions used were: $10 \times \mathrm{TE}$ (Tris-EDTA) buffer, $\mathrm{pH}$ 8.0, containing 10 $\mathrm{mm}$ Tris- $\mathrm{HCl}$ and $1 \mathrm{~mm}$ EDTA; 24 chloroform : 1 isoamyl alcohol; $3 \mathrm{~m}$ sodium acetate; $1 \mathrm{M} \mathrm{NaCl}$; absolute ethanol and 70\% ethanol; deionized distilled water; and RNAase A $10 \mathrm{mg} \cdot \mathrm{mL}^{-1}$ stock.

We ground $\approx 8 \mathrm{~g}$ of cactus pear tissue in a cold mortar with liquid nitrogen. The powder was transferred to a $125-\mathrm{mL}$ flask containing $25 \mathrm{~mL}$ of extraction buffer. To adjust sample size in the first attempts, the tissue was added in small $(1-2 \mathrm{~g})$ batches and mixed thoroughly before adding the next batch. Once the solution started to thicken, we stopped adding 
tissue. The following extractions were performed, adding ground tissue in a single batch. The mixture was incubated in a water bath at $60^{\circ} \mathrm{C}$ for $25 \mathrm{~min}$, then removed and allowed to cool to room temperature. Ten milliliters of chloroform/isoamyl alcohol were added, and the mixture was incubated at room temperature for an additional $5 \mathrm{~min}$. The solution was centrifuged at $5000 g_{\mathrm{n}}$ for $20 \mathrm{~min}$ at $18-20^{\circ} \mathrm{C}$. The supernatant was filtered through Miracloth $^{\circledR}$, diluted with two volumes of separation buffer and incubated $30 \mathrm{~min}$ at room temperature. The solution was then subjected to a second centrifugation at $15,000 g_{\mathrm{n}}$ for 20 $\min$ at $18-20^{\circ} \mathrm{C}$. In the next step, the supernatant was discarded by draining the tube thoroughly to eliminate as much of the CTAB as possible. The pellets were dissolved in $3.5 \mathrm{~mL}$ of $1 \mathrm{M} \mathrm{NaCl}$ and incubated for 15-30 min at room temperature. CTAB is a cationic detergent that precipitates nucleic acids when the salt concentration is reduced below $0.4 \mathrm{M}$, leaving the neutral polysaccharides in solution. The DNA-CTAB pellet is then treated with $\mathrm{NaCl}$ so that the $\mathrm{Na}$ exchanges with the CTAB, leaving clean DNA (Gottlieb et al., unpublished data). The DNA was precipitated by adding 2.5 volumes of $100 \%$ ethanol. We spooled the DNA with a bent glass pipette and air-dried it for 2-5 min, depending on the size of the pellet. The DNA pellet was resuspended in 100-300 $\mu \mathrm{L}$ of TE or deionized distilled water. The tubes were heated at $65^{\circ} \mathrm{C}$ for $\approx 2$ min to redissolve the DNA and then stored overnight at $4{ }^{\circ} \mathrm{C}$. The following day, they were centrifuged for $2 \mathrm{~min}$ to pelletize the undissolved material. The liquid phase was transferred into a clean Eppendorf tube. To eliminate RNA, the samples were treated with $5 \mu \mathrm{L}$ of RNAase A and incubated at $37^{\circ} \mathrm{C}$ for $40 \mathrm{~min}$

In our trials, we found that two different phases could be present after the second centrifugation. The first one produced a transparent pellet of DNA that dissolved easily. A second extraction can be performed on the thick green fraction if desired. For the second purification, we centrifuged the solution for $10 \mathrm{~min}$ at $13,000 \mathrm{~g}_{\mathrm{n}}$. The supernatant was decanted to a new tube, $75 \mu \mathrm{L}$ of sodium acetate $3 \mathrm{M}$ (pH 5.2) and $0.5 \mathrm{~mL}$ of isopropanol were added and the tube was centrifuged for 5 min. The supernatant was removed, and the DNA pellet was washed with $100 \mu \mathrm{L}$ of ethanol and air-dried for $30 \mathrm{~min}$. Finally, the pellets were resuspended in 100-200 $\mu$ L of sterile water or TE and treated with RNAase A.

DNA assessment. The concentration and quality of DNA were determined spectrophotometrically to calculate the 260:280 ratio. The usefulness of DNA isolated from cacti for polymerase chain reaction (PCR) is one way to evaluate the success of any DNA extraction. A modification by Conner et al. (1997) of the original protocol (Williams et al., 1990) used to study apple (Malus $\times$ domestica Borkh.) cultivars was followed for the cacti samples. The PCR reactions were performed according to the following conditions: initial denaturation of $95^{\circ} \mathrm{C}$ for $5 \mathrm{~min}$; denaturation at $95^{\circ} \mathrm{C}$ for $30 \mathrm{~s}$; annealing at $45^{\circ} \mathrm{C}$ for $1 \mathrm{~min}$; exten- sion at $72{ }^{\circ} \mathrm{C}$ for $1 \mathrm{~min}$; and a final extension of $5 \mathrm{~min}$ at $72{ }^{\circ} \mathrm{C}$. We ran the reactions for 40 cycles. The PCR reactions were repeated three times, using the same conditions, to check repeatability of amplification products both within and between reactions. The PCR amplifications were performed on a PTC100 Programmable Thermal Controller (MJ Research, Waltham, Mass.). Each reaction included 2.5 $\mu \mathrm{L}$ of $10 \times$ PCR buffer, $1.25 \mu \mathrm{L}$ of $2.5 \mathrm{~mm}$ deoxynucleotides, one unit of Taq polymerase, $1.5 \mu \mathrm{L}$ of $10 \mathrm{~mm}$ primer, and $2.5 \mu \mathrm{L}$ of $25 \mathrm{~mm}$ $\mathrm{MgCl}_{2}$. We used $\approx 20 \mathrm{ng}$ of genomic DNA as a template. The final volumes of the reactions were $25 \mu \mathrm{L}$.

\section{Results and Discussion}

Isolation of high-quality DNA from different cacti species and cultivars was difficult using some protocols available for several cultivated plants. Miniprep methods (Haymes, 1996; Rowland and Nguyen, 1993) using small amounts of tissue $(<2 \mathrm{~g})$ in microfuge tubes presented difficulties when attempted with tissue of these particular plants. Methods that used only a single extraction step, either CTAB or sodium dodecylsulphate (SDS), did not eliminate the problem of sample thickness, which later interfered with centrifugation and separation of the coarse material. The mucilage released by the macerated tissue was the main problem encountered. These compounds bind the water present in the extraction buffer, preventing further processing.

The amount of mucilage present in a particular species was highly variable and the final sample size had to be adjusted by species and tissue condition. The goal is to avoid excess mucilage to maintain the solution fluid in order to allow efficient centrifugation. We found that for Opuntia and Nopalea 5-8 g was sufficient, and for Stenocereus, Cleistocactus and Echinocereus, 4-6 g was needed. For mature Opuntia tissues, 5-6 g were needed.

After the first centrifugation, the upper aqueous phase in these samples was still thick and slimy. With our method, we found that adjusting the size of the sample reduced this effect. We carefully extracted the top phase with a Pasteur pipette, avoiding disturbance of the interface or contamination with isoamyl alcohol. We also added some of the separation buffer to the Miracloth ${ }^{\circledR}$ to reduce viscosity and accelerate filtration. Incubation with the extraction buffer in the next step further reduced the viscosity of the sample. Addition of the separation buffer containing 2\% CTAB after the chloroform extraction further reduced viscosity, allowing the separation of DNA. According to Barnwell et al. (1998), the most widely used method to avoid co-precipitation of polysaccharides and DNA is to keep the polysaccharides in solution at the DNA precipitation step, usually by using CTAB.

Centrifuging for $15 \mathrm{~min}$, as the original protocol stated, produced a loose mass that impeded liquid phase separation without contamination, therefore preventing DNA extraction. Increasing centrifugation time to 20 min improved adherence of the solid phase to the tube and allowed separation of debris and supernatant after cell disruption.

Old tissues after the second centrifugation often produced a large, thick, green pellet (color is due to residual chlorophyll and mucilage), along with a small colorless pellet. They were processed separately and the purity assessed individually. Additional DNA was recovered from these pellets following the procedure described in the last four steps. Overall quality of the DNA recovered from the large pellets is slightly lower than that produced by the small ones from the lighter phase of the sample, but this DNA can also be amplified. However, the colorless pellet usually fulfills the quality criteria without additional processing.

We isolated DNA from 32 accessions of cactus pear, including wild (tetraploid and hexaploid) and cultivated (octoploid) representatives of these species. Morphology varies enormously in the Cactaceae, and some specific traits pertaining to DNA extraction (e.g., content of mucilages, fiber, and waxes) are highly variable. The suitability of our protocol for other genera was demonstrated for Nopalea cochellinifera Salm-Dyck (another edible cactus), Echinocactus sp. (a spherical ornamental), Stenocereus pruinosis

Table 1. Yield and absorbance ratios of DNA from eight cactus species.

\begin{tabular}{lcc}
\hline \hline Species & $\begin{array}{c}\text { DNA yield } \\
\left(\mu \mathrm{g} \cdot \mathrm{g}^{-1} \text { fresh weight }\right)\end{array}$ & $\begin{array}{c}\text { OD ratio } \\
260: 280\end{array}$ \\
\hline Cleistocactus sp. & $25 \pm 3.8^{z}$ & 1.5 \\
Cleistocactus sp. & $18 \pm 2.1$ & 1.5 \\
Echinocereus sp. & $49 \pm 8.4$ & 1.7 \\
Nopalea cochellinifera & $137 \pm 25.0$ & 2.0 \\
Opuntia albicarpa & $153 \pm 15.6$ & 1.7 \\
O. albicarpa (old tissue) & $113 \pm 12.8$ & 1.6 \\
O. albicarpa & $132 \pm 17.2$ & 1.7 \\
O. ficus-indica & $29 \pm 5.2$ & 1.5 \\
O. humifusa & $54 \pm 14.7$ & 1.8 \\
O. robusta 'A' & $64 \pm 11.9$ & 1.8 \\
O. robusta 'B' & $116 \pm 23.1$ & 1.9 \\
Stenocereus pruinosus & $53 \pm 10.1$ & 1.8 \\
\hline
\end{tabular}

${ }^{2}$ Means and standard deviations for six to eight (Opuntia sp.) or four (other species) samples. Except for $O$. albicarpa and Cleistocactus sp. $(5 \mathrm{~g}), \approx 8 \mathrm{~g}$ of tissue was used per sample.

${ }^{y}$ Cultivated species. 


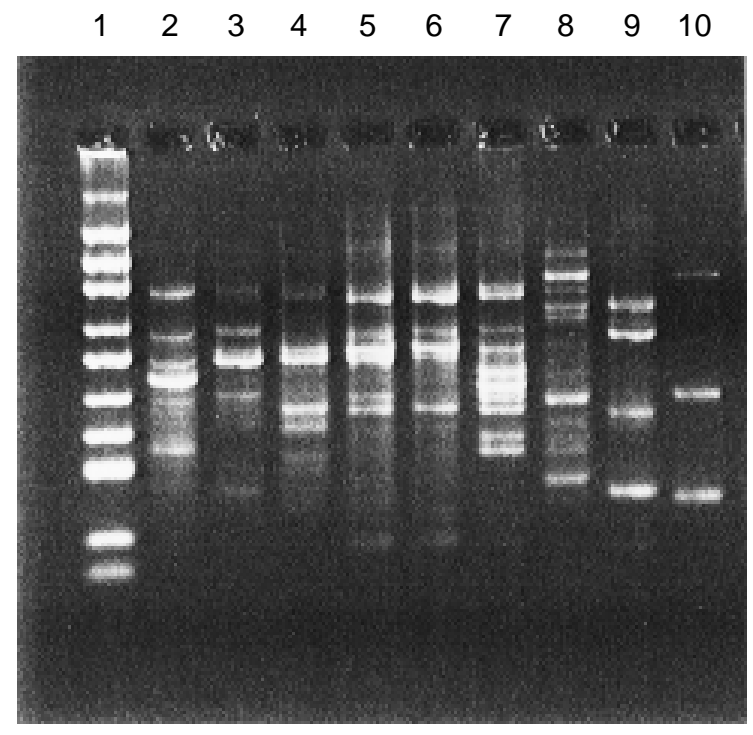

Fig 1. PCR amplification of genomic DNA of nine cactus samples with the primer OPG 03 (Operon Technologies, Alameda, Calif.) on 1.6\% agarose gel stained with ethidium bromide. Bands were compared with the DNA molecular weight marker pUC19 from Biosynthesis (Lane 1). O. humifusa, lane 2; O. robusta, lanes 3 and 4; O. albicarpa, lane 5; O. ficus-indica lane 6; N. cochellinifera lane 7; Cleistocactus sp. lane 8; Stenocereus sp. 9; Echinocereus sp. lane 10.

(a columnar cactus related to a semidomesticated cactus that produces edible fruits), and Cleistocactus sp. We followed the same procedure, closely watching the amount of mucilage released by the tissues and making the proper adjustments to the sample size. The final overall results showed very acceptable performance for all the species tested (Table 1).

In our trials, DNA yield varied from 29 $\mu \mathrm{g} \cdot \mathrm{g}^{-1}$ of fresh weight in O. ficus-indica to 153 $\mu \mathrm{g} \cdot \mathrm{g}^{-1}$ for $O$. albicarpa, and OD ratio ranged from 1.5 to 2.0 (Table 1 ). The banding patterns obtained with the decaprimer OPG 03: GAGCCCTCCA from Operon Technologies
(Alameda, Calif.) showed bright, well-defined bands that could be scored reliably for differences among accessions (Fig. 1).

This protocol uses standard equipment that is available in laboratories doing simple molecular biology or biochemistry studies. The chemicals and glassware are affordable. A batch of four samples can be processed simultaneously; the number can be increased to eight samples when using tender tissue, requiring 3-4 h per batch.

\section{Literature Cited}

Barnwell, P., A. Blanchard, J. Bryant, N. Smirnoff, and F. Weir. 1998. Isolation of DNA from the highly mucilagenous succulent plant Sedum telephium. Plant Mol. Biol. Rptr. 16:133-138.

Cardenas, A.I. Higuera-Ciapara, and F.M. Goicoolea. 1997. Rheology and aggregation of cactus (Opuntia ficus-indica) mucilage in solution. J. Prof. Assn. Cactus Dev. 2:152-159.

Conner, J.P., S.K. Brown, and F.N. Weeden. 1997. Random amplified polymorphic DNA based genetic linkage maps of three apple cultivars. J. Amer. Soc. Hort. Sci. 122:350-359.

Dellaporta, S.L., L.J. Wood, and J.B. Hichs. 1983. A plant DNA micropreparation: Version II. Plant Mol. Biol. Rptr. 1:19-21.

Doyle, J.J. and J.L. Doyle. 1990. Isolation of plant DNA from fresh tissue. Focus 12:13-15.

Goldstein, G. and P.S. Nobel. 1991. Changes in osmotic pressure and mucilage during lowtemperature acclimation of Opuntia ficusindica. Plant Physiol. 97:954-961.

Haymes, M.K. 1996. Miniprep method suitable for a plant breeding program. Plant Mol. Biol. Rptr. 14(3):280-284.

Loik, M. E. and P.S. Nobel. 1991. Water relations and mucopolysaccharide increases for a winter hardy cactus during acclimation to subzero temperatures. Oecologia 88:340-346.

Mizrahi, Y., N. Avinoam, and P.S. Nobel. 1997. Cacti as crops. Hort. Rev. 18:291-346.

Nobel, P.S. 1988. Environmental biology of agaves and cacti. Cambridge Univ. Press, Cambridge, U.K.

Nobel, P.S. 1994. Remarkable agaves and cacti. Oxford Univ. Press. Oxford, U.K.

Nobel, P.S., J. Cavalier, and J.L. Andrade. 1992. Mucilage in cacti: Its apoplastic capacitance, associated solutes, and influence on tissue water relations. J. Expt. Bot. 43:641-648.

Rowland, L.J. and B. Nguyen. 1993. Use of polyethylene glycol for purification of DNA from leaf tissue of woody plants. Biofeedback 14:735-736.

Varadarajan, G.S. and C.S. Prakash. 1991. A rapid and efficient method for the extraction of total DNA from the sweet potato and its related species. Plant Mol. Biol. Rptr. 9:6-12.

Williams, J.G. K., A.R. Kubelik, J.L. Kenneth, and J.A. Rafalski. 1990. DNA polymorphisms amplified by arbitrary primers are useful as genetic markers. Nucleic Acid. Res. 18:6531-6535. 